\title{
Product Liability Issues in the U.S. and Associated Risk Management
}

\author{
Stephen S.Wu
}

\section{Content}

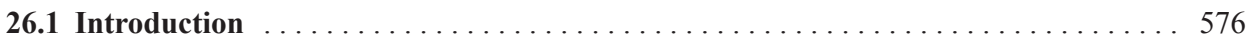

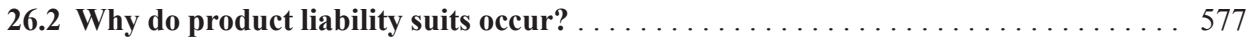

26.3 More recent high-profile product liability litigation . . . . . . . . . . . . . . . 579

26.3.1 "Sudden acceleration" litigation . . . . . . . . . . . . . . . . . . . . . . . . 580

26.3.2 General Motors ignition switch issues and recall ............... 581

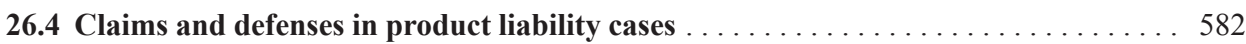

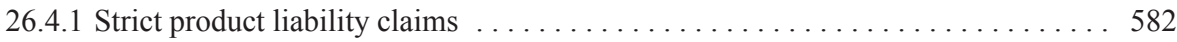

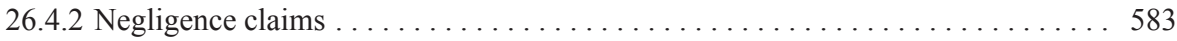

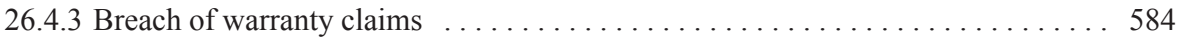

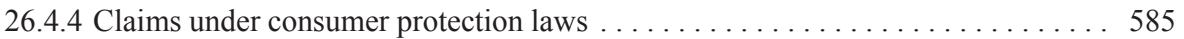

26.4.5 Types of defects at issue in autonomous vehicle litigation . . . . . . . . 585

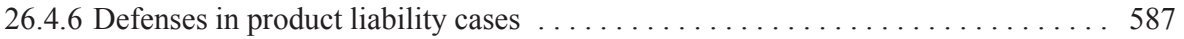

26.5 Managing the risk of autonomous vehicle product liability $\ldots \ldots \ldots \ldots \ldots \ldots 88$

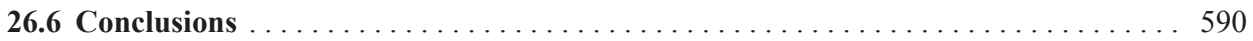

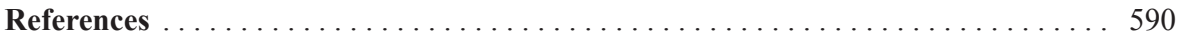

\section{S.S. Wu $(\square)$}

USA

ssw@svlg.com 


\subsection{Introduction}

Autonomous vehicles (AVs) hold the promise of saving tens of thousands of lives each year in the U.S., and many more worldwide, reducing traffic, saving energy, and providing mobility to those who cannot drive conventional cars. Nonetheless, AVs will inevitably have some accidents. On balance, AVs are likely to prevent many more accidents than they cause, but there will be at least some accidents involving AVs that would not have occurred with conventional vehicles.

Because of accidents involving AVs, some of which may be catastrophic, product liability litigation ${ }^{1}$ is inevitable, especially in cases where conventional vehicles would not have crashed. The threat of massive product liability litigation involving AVs is widely perceived as one of the chief obstacles to AV development and sales, if not the number one threat [3]. ${ }^{2}$ Some believe that product liability suits may be an existential threat to autonomous driving [33]. ${ }^{3}$ Crippling suits could force manufacturers to exit the market and may deter some manufacturers from entering the market because of a belief that the sales are not worth the risk. If these dire predictions come to pass, the U.S. and other parts of the world experiencing a flood of lawsuits may lose the use of a technology that would save many times more lives than it would endanger. If, however, the industry finds effective ways to manage the risk of product liability, it can bring to market a lifesaving technology while maintaining practices to minimize accidents and resulting liability, as well as the profitability needed to offer AVs in the market over time.

The purpose of this chapter is to identify product liability risks in the U.S. to manufacturers of AVs, the source of those risks, and how manufacturers can manage those risks. A focus on U.S. product liability is important from a worldwide manufacturer's perspective given the size of the U.S. market and the perception that the U.S. is a litigious country. Product liability is perceived as a greater threat in the U.S. than in any other country of the world. Section 26.2 discusses the circumstances giving rise to U.S. product liability litigation and the phenomenon of some U.S. cases resulting in huge awards to plaintiffs seeking compensation. It explains why these huge awards occur. Section 26.3 analyzes the human and financial impacts of more recent high profile product liability cases. Section 26.4 discusses U.S. product liability law, focusing on the types of claims and defenses arising in product liability cases. Section 26.5 covers design practices and procedures that manufacturers can use to reduce the risk of product liability, the use of

1 This chapter focuses mainly on product liability litigation, although there are also requirements to compel vehicle manufacturers to recall their vehicles to fix defects. The management of liability and recall risks overlap and the risk management principles discussed in this chapter apply to both.

2 "Some of the largest obstacles to autonomous consumer vehicles are the legalities [3]." Reports from Lloyd's of London and the University of Texas listed product liability as among the top obstacles for AVs [21] [30].

3 " $[\mathrm{T}]$ he worst outcome would be that said liability isn't sorted out so that we never do get the mass manufacturing and adoption of driverless cars." [33] 
insurance as a means of shifting and managing product liability risk, and other risk management techniques.

\subsection{Why do product liability suits occur?}

First and foremost, manufacturers face product liability suits, because their products are involved in accidents. From the early days in the development of Anglo-American tort ${ }^{4}$ law, the road accident played a prominent role. A key British case in the development of U.S. tort law, Winterbottom v. Wright, ${ }^{5}$ involved a mail coach driver who was thrown from his horse-drawn mail carriage after it broke down, allegedly due to the defendant contractor's failure to maintain the carriage in a safe condition [32]. ${ }^{6}$

Starting in the 20th century, the car accident caused significant changes in U.S. product liability law. "Products liability, like America, grew up with the automobile. Prior to the entry of motorcars onto the nation's highways, 'there simply were not large numbers of product-related lawsuits.' Once America embraced the automobile, it inevitably embraced automotive products suits as well." [13] Two of the most significant products liability cases in American history arose from auto accidents. In MacPherson v. Buick Motor Co., the famous American jurist Benjamin Cardozo writing for the New York Court of Appeals upheld a verdict for a car owner ejected from his Buick car after a defective wooden wheel on the car collapsed [22]. ${ }^{7}$ In Henningsen v. Bloomfield Motors, Inc. [17], ${ }^{8}$ the New Jersey Supreme Court affirmed a jury verdict against Chrysler and a dealer after the wife of the purchaser had an accident. She testified that she felt something crack in the car, the steering wheel spun sharply, the car veered off the road, and the car struck a highway sign and brick wall.

The threadbare descriptions of the car accidents in these appellate courts' decisions, however, do not reflect the reality of the trial setting in which lawyers for the injured plaintiffs will describe what might be a catastrophic car accident in unvarnished and sometimes horrific terms. Consider a description of the famous Ford Pinto accident written in Mother

4 "Tort" means "wrong," and "tort law" provides a mechanism for a plaintiff to seek redress in a civil (i.e., non-criminal) case.

5 It was common in the 19th century for American courts to cite contemporary British cases as precedents.

6 In Winterbottom, the court denied relief to the injured coachman because of a lack of direct contractual relationship, called "privity," between the plaintiff coachman and the defendant contractor. The coachman was not a party the contract in which the defendant contractor promised to maintain the coach in good working order [32].

7 The plaintiff had bought the car from a retailer, but could still sue the manufacturer despite the lack of privity with the manufacturer [22]. The car was apparently going 8 miles per hour at the time of the accident [13].

8 The court rejected privity, a warranty disclaimer, and limits of liability as defenses to the warranty claim of the wife driver of the car and her husband, the owner [17]. 
Jones magazine. Although the description below comes from a writer, ${ }^{9}$ it is similar in tone and impact to what a plaintiff's lawyer might say about his or her client in an opening statement. Here is how the writer describes the accident:

\begin{abstract}
[A] woman, whom for legal reasons we will call Sandra Gillespie, pulled onto a Minneapolis highway in her new Ford Pinto. Riding with her was a young boy, whom we'll call Robbie Carlton. As she entered a merge lane, Sandra Gillespie's car stalled. Another car rear-ended hers at an impact speed of 28 miles per hour. The Pinto's gas tank ruptured. Vapors from it mixed quickly with the air in the passenger compartment. A spark ignited the mixture and the car exploded in a ball of fire. Sandra died in agony a few hours later in an emergency hospital. Her passenger, 13-year-old Robbie Carlton, is still alive; he has just come home from another futile operation aimed at grafting a new ear and nose from skin on the few unscarred portions of his badly burned body. [11]
\end{abstract}

In the courtroom, the young boy, so badly disfigured by the accident, would likely be sitting next to his attorney during the entire trial. The jury would be seated facing him, and watching him. The unspoken testimony of his catastrophic injuries would likely have at least an unconscious effect on the jurors watching him. Despite instructions from the judge not to permit sympathy, bias, or prejudice to sway their verdict, a car manufacturer defending this case would have an difficult time at trial. In the Ford Pinto case, the 13-year-old boy, whose real name was Richard Grimshaw, received a jury award in the amount of over $\$ 2.5$ million in compensatory damages and an award of punitive damages to punish and deter Ford in the amount of \$125 million [15]. Part of the motivation for the large verdict was evidence during the trial of Ford's apparently cold-hearted decision not to use fairly inexpensive parts in its cars that would have prevented the accident. Although the punitive damages award was later reduced in this case to $\$ 3.5$ million [15], the Ford Pinto case shows the kind of award that is possible in an automobile product liability case following a catastrophic accident.

At some future time when an AV manufacturer faces a product liability trial, we can expect to see accident victims seated in a courtroom with similar gruesome disfigurements and stories of out-of-control cars and tragic, frightful accidents. The defendant manufacturer's engineering and business practices will come under scrutiny. And a jury will likely decide whether or not the manufacturer should be held responsible for the accidents.

During an AV's design phase, its manufacturer's design team will have an opportunity to discuss and make engineering and business decisions about the design of its AVs. Team members will talk about safety efforts the manufacturer is willing to undertake. In these discussions, team members can think more clearly and assess risk more effectively by imagining themselves in a courtroom setting, defending their practices in litigation arising from a catastrophic accident.

9 The writer is using pseudonyms for the names of the crash victims, evidently before the names of the victims became public. 
Why are jurors willing to render these large verdicts against manufacturers? The short answer is juror anger. "Angry jurors mean high damages." [24] More specifically, juries render large verdicts when they become angry at defendants' conduct. When juries become angry, the only way that they see they can redress the defendants' wrongs is to render very large verdicts against them in an effort to send a message that their conduct is unacceptable.

In the Ford Pinto case, the jury heard evidence that Ford had known about the problems with its fuel system. Ford had found the problem of rear-end crashes splitting open the Pinto's gas tank. In addition, Ford knew that a part costing \$11 could have prevented the accident. Nonetheless, Ford made a cost/benefit analysis comparing the overall cost of adding the safety part to the vehicle against the value of the lives lost from accidents involving the vulnerability. Ford assigned a value to each human life likely lost. And Ford decided that the overall cost of the part exceeded the overall value of the human lives that would be saved and determined that it therefore should not add the part to the Pinto's design.

Ford's cost/benefit calculation seemed odious to the jury because it placed a dollar value on human life. In addition, the jury knew that the extra part would only cost $\$ 11$. By not adding the part to the Pinto's design, the jury evidently concluded that Ford placed its profits ahead of human life. Ford's apparent callousness led to the jury anger [15].

In another famous product liability case, a Texas lawyer obtained a \$253.5 million verdict against pharmaceutical company Merck for Carol Ernst, the widow of Robert Ernst. Mr. Ernst died after having taken Merck's painkiller Vioxx for eight months [5]. The jury saw internal Merck documents showing that the company was aware of the heart attack risk to users before it started marketing the drug. The documents gave the jury the impression that the company cared more about profits than public safety. As a result, the jury tried, via the huge award, to send a message that it is wrong to hide information about a drug's danger [14]. Although an appellate court later overturned the jury's verdict, again the case underscores the risk of huge product liability verdicts [23].

\subsection{More recent high-profile product liability litigation}

As noted in the previous section, appellate courts provided some relief to Ford and overturned the verdict in the Vioxx case. Nonetheless, manufacturers should look to two more recent sets of cases in order to analyze the potential human and financial impact of product liability issues. Section 26.3.1 covers the so-called "sudden acceleration" phenomenon involving Toyota cars. Section 26.3.2 describes the fallout from the General Motors ignition switch defects. These two cases show how manufacturers may need to pay huge sums to resolve product liability legal proceedings, which are in addition to the human toll of deaths and injuries. 


\subsection{1 "Sudden acceleration" litigation}

Several years ago, news stories emerged concerning a phenomenon in which Toyota drivers reported that their cars accelerated without warning and were difficult to stop, resulting in accidents. One typical news report stated, "Nancy Bernstein feels lucky to be alive after her Toyota Prius kept accelerating, no matter how hard she hit the brakes. 'The car's going about 70 miles an hour, and I'm beginning to get scared because it's not slowing down,' Bernstein described." [26]. Lawsuits followed these accidents, and federal cases were transferred to the U.S. District Court for the Central District of California for coordinated or consolidated pretrial proceedings [27].

Some reports contend that the 89 people may have died from accidents involving the sudden acceleration of Toyota vehicles [10]. Governmental investigations, however, showed no evidence that design or implementation flaws in Toyotas caused unintended acceleration [25]. Accordingly, there was some controversy about whether Toyota or drivers were at fault in these accidents.

Later in the litigation, however, a report by expert witness Michael Barr following additional research opined that a software malfunction occurred in one of the cars and that the malfunction resulted in unintended acceleration [4]. Barr identified numerous alleged problems with the software, which according to Barr, Toyota's own engineers had trouble understanding and characterized as "spaghetti like" [4]. Barr testified about his findings in an Oklahoma state court case and, apparently based in part on these findings, the jury in the case awarded compensatory damages of $\$ 1.5$ million to the driver and $\$ 1.5$ million to the family of a passenger who died in the crash [35]. The parties in the case, Bookout $v$. Toyota Motor Corp. [7], settled the case right before a second phase of the trial to consider punitive damages against Toyota [18].

Despite the uncertainty about what really caused these accidents, Toyota started to settle the various legal actions against the company. The Oklahoma case may have been a motivating factor [28]. ${ }^{10}$ Toyota's settlement payments so far include:

- $\$ 1.6$ billion to settle financial loss claims in the multidistrict litigation [28].

- $\$ 1.2$ billion to settle potential criminal charges against Toyota [29].

- \$25.5 million to settle shareholder claims arising the failure to report safety issues [29].

- $\$ 65$ million in fines for violations of federal vehicle safety laws [29].

These settlement payouts are in addition to the numerous product liability lawsuits that remain pending, the settlement of which presumably will cost a huge sum. If product liability settlement amounts exceed $\$ 1$ billion, then the total settlements may exceed $\$ 4$ billion. The cost of legal fees and other internal expenses related to investigation and remedial measures will add even more to the final cost for Toyota.

10 "Legal analysts said that the verdict most likely spurred Toyota to pursue a broad settlement of its remaining cases." [28] 


\subsubsection{General Motors ignition switch issues and recall}

Another high-profile product liability issue arose from the recently uncovered problem with ignition switches in certain General Motors cars. In the late 1990s, GM started using new switches for small cars to make them work more smoothly. "But as it turns out, new switches in models such as the Chevrolet Cobalt and Saturn Ion can unexpectedly slip from 'run' to 'accessory,' causing engines to stall. That shuts off the power steering, making cars harder to control, and disables air bags in crashes [20]. The problem supposedly caused over 50 accidents. "GM says the problem has caused at least 13 deaths, but some members of Congress put the death toll near 100." [20]

Apparently, GM engineers were aware of the problem before the accidents, but decided not to replace the switches. An internal email uncovered in Congressional hearings discussed the fact that a more robust design would add 90 cents to the price of the switch, and would only save 10-15 cents in reduced warranty claims [16]. "The part costs less than $\$ 10$ wholesale. The fix takes less than an hour. A mechanic removes a few screws and connectors, takes off a plastic shroud, pops in the new switch, and the customer is back on the road." [12] "[T] many people familiar with the automaker," the reason GM did not recall the cars sooner "is a corporate culture reluctant to pass along bad news. When GM was struggling to cut costs and buff its image, a recall of its popular small cars would have been a terrible setback." [12] "It's pretty clear that somebody somewhere was being penny-wise and pound-foolish,' said Marina Whitman, a professor at the University of Michigan and a former economist at GM.” [12]

GM's decision not to recall the cars sooner is proving to be a costly one. Congress, safety regulators, the U.S. attorney in New York City, the SEC, Transport Canada, and 45 state attorneys general are conducting probes of GM. GM is undertaking a costly recall of the cars. Also, GM created a compensation fund for families of crash victims, which it expects will cost the company $\$ 400$ million to $\$ 600$ million [19].

In addition to the compensation fund, GM said that it will spend $\$ 1.2$ billion to repair the cars and trucks recalled during the second quarter, on top of the $\$ 1.3$ billion it identified for repair costs in the first three months of the year. In addition, the company set aside an additional $\$ 874$ million in the quarter for future recalls. [19]

The total expense for GM will be huge: "All told, GM's recalls have cost the automaker nearly $\$ 4$ billion this year." [19] Presumably, GM will continue to pay more in future years as well. Moreover, GM will have to pay even more for legal fees and other internal expenses related to investigation and remedial measures. 


\subsection{Claims and defenses in product liability cases}

Having covered the phenomenon of product liability litigation, the human toll of accidents, and the large financial risks involved, this section covers what plaintiffs must prove in order to prevail in a suit based on an allegedly defective product, as well as what defendants must prove in order to assert certain defenses. Typical claims for plaintiffs seeking damages for bodily injury or property damage from an accident are "strict product liability," "negligence," and "breach of warranty." 11 Most of the law governing product liability in the U.S. is state law, as opposed to federal law, and laws diverge from state to state.

\subsubsection{Strict product liability claims}

The easiest type of claim for a plaintiff to prove is a so-called "strict product liability" claim. A plaintiff can include in the suit almost every business in the chain of distribution from raw materials or component part manufacturers to manufacturers of the finished product, distributors, and retailers [13]. Strict liability refers to liability for defective products without fault on the part of the manufacturer and regardless of whether or not there is a contractual relationship between the plaintiff and defendant. Laws vary significantly from state to state, and some states do not even recognize strict liability as a viable claim. Nonetheless, most states' statutory and common law strict liability laws are based on the formulation of strict liability under Section 402A of the Second Restatement of Torts [2]. ${ }^{12}$ As stated in the Restatement, in order to win a strict liability claim, the plaintiff must prove at trial:

- The defendant sold the product in question,

- The defendant is in the business of selling this kind of product,

- The product was defective and unreasonably dangerous at the time it left the defendant's hands,

- The product is expected to and does reach the user or consumer without substantial change in the condition in which it is sold, and

- The defect was the proximate cause of the plaintiff's injuries [2].

The key issue for AV strict liability design defect claims will be whether the vehicle was "defective." A plaintiff may assert that the product was defective in its design, the product was defective in the way it was manufactured, and/or that the defendant failed to provide

11 Another theory of recovery for plaintiffs is fraud, also known as "deceit" or "misrepresentation," and is based on false statements made by the seller about a product. Misrepresentations may be intentional, negligent (careless), or innocent. This type of claim, however, is the least used theory of recovery in the product liability context [13].

12 "More than three quarters of American jurisdictions incorporate all or part of this section in their own distinct brand of strict liability." [13] Restatements of law summarize an area of law in the U.S., but do not themselves have the force of law. 
adequate warnings or instructions to the users of the product. Of greatest concern for $\mathrm{AV}$ litigation are design defect and failure to warn claims.

A plaintiff asserting a design defect would show the existence of a "defect" under the applicable state law test. Courts in the U.S. apply one of the following tests:

- A test based on what an ordinary consumer would expect from a product, typically used where the potential for injury is clear to consumers from the nature of the product.

- The risk-utility balancing test, where the plaintiff contends that the risks from a design outweigh the benefits to the consumer or public from a design.

- The product manufacturer test, which asks whether a reasonably prudent manufacturer or seller, aware of the product's dangerous condition, would not have put the product on the market if it had been aware of the product's condition.

- A combination test, which may shift the burden of proof to the manufacturer to show a lack of defect in certain situations.

- The ultimate issue approach, in which the jury has the discretion to determine whether a design is defective [31].

Frequently, a plaintiff asserting a design defect will use expert testimony to explain why the defendant's design is defective and will attempt to prove that an alternative design could have prevented the accident.

In addition to relying on design defects, a plaintiff may also assert a strict liability claim based on a "failure to warn" theory. Under this theory, the plaintiff could contend that an $\mathrm{AV}$ was defective because the defendant failed to provide adequate warnings or instructions about the vehicle. The plaintiff would need to prove that the warnings did not adequately reduce risks associated with the product or that the instructions were inadequate to tell the user how to use the product.

\subsubsection{Negligence claims}

As an alternative claim, product liability plaintiffs often include a negligence claim in their complaints. The concept of "negligence" refers to careless conduct that falls below the standard of conduct to which a hypothetical "reasonable man" would adhere. As with strict liability, a plaintiff can assert a negligence claim based on the design of the product, the way in which the product was manufactured, or the failure to give adequate warnings or instructions. Negligence is a harder claim for a plaintiff than strict liability, because the plaintiff must show some degree of fault on the part of the defendant.

In order to prevail in a negligence claim, the plaintiff must prove:

- The defendant owed a duty of care to provide a reasonably safe product in terms of design or to warn of dangerous defects - meeting a standard of conduct to protect others against unreasonable risk, 
- The defendant breached its duty of care by failing to conform its conduct to the standard of conduct required, and

- The defendant's conduct proximately caused the plaintiff's injury [31].

\subsubsection{Breach of warranty claims}

In most states in the U.S., a plaintiff may also include a breach of warranty claim in a product liability complaint. Warranties are affirmations or promises concerning a product or its performance, features, or characteristics, such as those concerning the safety of a product. The basis of a breach of warranty claim is that the seller's product does not perform as promised, or does not have the features or characteristics promised. Design defects, manufacturing defects, or failures to warn may all provide the basis for a warranty claim. As with strict liability, the question is whether or not the product adheres to the promises made, regardless of whether the seller is at fault for the failure to conform to the promise. Nonetheless, warranty claims are subject to defenses with various degrees of effectiveness, including the historical defense of "privity" (plaintiff's lack of contractual relationship with the defendant), the requirement that the plaintiff provide the seller notice of the breach, and the ability for sellers to disclaim warranties [31]. In most U.S. jurisdictions, purchasers of a product or their family members can sue companies in the chain of distribution under a warranty theory despite the lack of privity [31].

In order to assert a breach of warranty claim, a plaintiff must typically prove:

- The defendant made a warranty,

- The product did not comply with the warranty at the time of the sale,

- The plaintiff's injury was proximately caused by the defective nature of the product, and

- As a result, the plaintiff suffered damage [31].

A warranty claim will typically allege one of three kinds of warranties. "Express warranties" are those actually stated by the seller, such as in a sales contract, warranty program documentation, advertisements, or sales collateral. They may be written or oral. In addition to the express warranties, the law will sometimes recognize two kinds of "implied warranties" regarding the sale of consumer products that arise by operation of law, as opposed to anything the seller actually said.

One kind of implied warranty is the "implied warranty of merchantability." This implied warranty requires the seller to make sure the product is fit for the ordinary purposes of such product. For instance, a consumer would expect that the head of a hammer would not fly off the first time it is used after purchase. This kind of implied warranty is the one most likely to be asserted against a seller of an AV in future cases. The second typical implied warranty is the "warranty of fitness for a particular purpose." Where the seller knows the particular purpose for which the consumer will use the product, and the buyer is relying on 
the skill and judgment of the seller to select and furnish suitable products, the law will recognize an implied warranty that the product will be fit for that purpose. For instance, if a truck buyer tells a dealer's sales representative that the buyer seeks a pickup that will be able to tow a trailer through mountainous off-road terrain, then the dealer is deemed to have warranted that the truck recommended by the sales representative can, in fact, tow the trailer off-road in the mountains.

\subsubsection{Claims under consumer protection laws}

Plaintiffs sometimes assert product liability claims under various consumer protection laws. State laws vary, and some states do not permit these laws to be used for personal injuries [1]. They are commonly used when plaintiffs seek redress for alleged economic or financial losses, such as the diminution in the value of their products due to the alleged defect. Examples include California's Unfair Competition Law (UCL) [8], False Advertising Law (FAL) [8], and Consumer Legal Remedies Act (CLRA) [9], as well as equivalent laws in other states. Claims under these statutes typically require plaintiffs to prove:

- A violation of the statute occurred

- That causes

- Injury to a consumer.

For instance, the UCL prohibits unlawful, unfair, or fraudulent business acts or practices. The FAL bars untrue or misleading advertising practices. The CLRA prohibits a list of unfair business practices, such as misrepresenting the characteristics and qualities of a product.

\subsubsection{Types of defects at issue in autonomous vehicle litigation}

We do not yet have examples of cases filed against AV manufacturers to say what kinds of alleged defects will likely result in litigation. Nonetheless, the history of automotive litigation, discussions with those in the industry, and judgments about what is likely to come suggest that there will be many sources of potential defects that may give rise to product liability litigation. AVs will share some of these sources of defects with conventional vehicles, but some of them will be unique to AVs. The lists of potential defects in this section are not meant to be exclusive, and there are many possible sources of defects in conventional and autonomous vehicles.

Some possible design defects ${ }^{13}$ that $\mathrm{AV}$ s will have in common with conventional vehicles include:

13 Another issue for manufacturers of finished products concerns their supply chains. Counterfeit or defective components may introduce manufacturing defects into AVs. 
- Mechanical or physical defects in various systems of the vehicles or their safety equipment, such as the use of materials that are not strong or thick enough, ${ }^{14}$ or an excessively high center of gravity subjecting the vehicle to rollovers.

- Defects in electrical components or systems other than sensors or control systems for autonomous driving, such as the use of wrong kind of components, problems in the performance of the components, or the lack of durability of the components.

- Software ${ }^{15}$ defects relating to systems other than sensors or control systems for autonomous driving, including information security vulnerabilities.

These defects will occur in both conventional and autonomous vehicles and thus existing law and litigation methods would apply to determine a manufacturer's liability.

Nonetheless, AVs may experience defects that conventional vehicles do not. Again, they may be mechanical, electronic, or software.

- Mechanical or physical defects in the control systems for autonomous mode or the sensors used by the autonomous systems. A simple example would be weak mountings for LIDAR sensors which, if they failed, might cause the AV to lose its sensor data suddenly and crash.

- Defects in electrical components for sensors or control systems for autonomous driving.

- Software defects in the sensors or control systems used for autonomous mode.

The most interesting and perhaps most concerning potential defects are those in the software used for autonomous driving. Some examples include:

- Designs that depend on inadequate data from sensors, including insufficient amount, inaccuracy, deficient precision, or inadequate speed of data input.

- Inaccurate pattern recognition, such as the AV failing to be able to recognize a pedestrian in the road or other upcoming obstacles or hazards.

- Designs that fail to perform safe ordinary maneuvers such as turns, lane-keeping, distance-keeping, and merging.

- Other problems with autonomous behavior, such as unpredictable changes in speed or direction.

- Deficient collision avoidance algorithms.

- Information security vulnerabilities.

- Defects arising from inadequate human-computer coordination. For instance, if an AV switches between autonomous and manual mode, the AV must alert the driver before switching to manual mode and transition to human control safely.

14 For example, the author was involved in one case in which the plaintiff alleged that the metal in a car's tie rod was not strong enough, the metal fatigue experienced by ordinary wear of the car weakened the tie rod, and an accident occurred because metal fatigue caused the tie rod to break.

15 The "software" involved may be in the form of code built into hardware or firmware. 
Moreover, Chapter 4 discusses design decisions programmers must make when creating the logic for an AV to handle the situation of when a collision is imminent and unavoidable and there is a choice between striking and harming different persons. For instance, an AV may face the dilemma of striking a motorcycle rider wearing a helmet or one without a helmet, and a programmer might decide that it is better, if a collision is unavoidable, to strike one or the other. If the programmer makes such a decision and designs the software to implement that decision, this kind of design decision could be the subject of a product liability suit from the person struck by operation of the software.

\subsubsection{Defenses in product liability cases}

Defendants may assert a number of defenses against a product liability case. The most common types of defenses relate to the conduct of the plaintiff. In some cases, the defendant contends that the plaintiff's negligent conduct caused or contributed to an accident. The viability of a defense based on a plaintiff's own negligence depends on state law and the type of claim, but a defendant may also use it as evidence of a superseding cause of an accident. In addition, some accidents occur because a plaintiff misused or modified a product. In some cases, a plaintiff is said to have "assumed the risk" of an open, obvious hazard, such as the possibility of being struck by a golf ball on the links. Finally, a plaintiff may not be able to recover all damages if he or she failed in some way to mitigate the damages.

Many of these defenses may have limited application to persons driving AVs in autonomous mode. If the plaintiff was not in control of the vehicle at the time of the accident, the plaintiff could not have driven carelessly. Once AVs enter the mass market, a seller cannot realistically contend that the plaintiff assumed the risk of driving a vehicle using new and untested technology. Nonetheless, it is likely over time that some people will modify their AVs or try to abuse the sensors or control systems for fun. In these cases, if an accident occurs, the defendant may point to this conduct as a defense. Moreover, defenses based on a plaintiff's conduct could reduce or bar a plaintiff's recovery when the plaintiff was not a driver of the AV, such as a pedestrian carelessly (or intentionally) darting out in front of an AV faster than any human or machine could react.

The other key defense in AV litigation will likely be a "state of the art" defense to a design defect claim. The basis of this defense is that the manufacturer could not have produced a safer design at the time of sale because safer designs were not technologically feasible then. Such a defense is valid in some states while not in others [13]. ${ }^{16}$

16 Another typical product liability-specific defense is the economic loss doctrine, which bars product liability tort claims where the claimed damages are financial and not for bodily injury or damage to property other than the product itself. Moreover, federal law may preempt some state law claims, because U.S. federal law trumps state laws inconsistent with it. Also, if a product is meant to be used by a "sophisticated user" or provided by a "sophisticated intermediary," the seller may have a defense under certain circumstances, although this defense is unlikely to apply to AVs. Finally, if a manufacturer creates a product pursuant to government specification, it may have a "government contractor defense." 


\subsection{Managing the risk of autonomous vehicle product liability}

Having covered the nature of product liability, the potentially huge exposure for losses, juror anger that leads to huge jury verdicts, and the nature of product liability, I now turn to the issue of how manufacturers can manage the risk of product liability litigation. ${ }^{17}$ First and foremost, managing these risks requires a proactive approach. By planning today, manufacturers can be prepared for the inevitable suits later. First, planning can enable them to make safer products that are less likely to cause litigation-triggering accidents in the first place. Second, by planning ahead, manufacturers can increase their chances of winning the cases that accidents do trigger. A proactive approach to design safety with a comprehensive risk management program establishes upfront a manufacturer's commitment to safety. When the inevitable suit happens later, the manufacturer's counsel has a story to tell the jury as to why its products were safe and how the manufacturer cared about safety.

Second, manufacturers should consider the commitment they make to product safety using such a proactive approach. One commentator stated, "The most effective way for [counsel for] a corporate defendant to reduce anger toward his or her client is to show all the ways that the client went beyond what was required by the law or industry practice." [24]. Meeting minimum standards is insufficient because of juror skepticism about the rigor of standards set or influenced by industry and because jurors expect corporate clients to know more about product safety than a "reasonable person" - the standard for judging the conduct of defendants under the law [24]. "A successful defense can also be supported by walking jurors through the relevant manufacturing or decision-making process, showing all of the testing, checking, and follow-up actions that were included. Jurors who have no familiarity with complex business processes are often impressed with all of the thought that went into the process and all of the precautions that were taken." [24] Even though accidents do occur, and in any trial setting an accident or problem did occur, a defendant's proactive approach would show the jury that the manufacturer tried hard to do the right thing [24]. Consequently, efforts to go above and beyond the minimum standards would diffuse juror anger and mitigate the manufacturer's risk.

Third, manufacturers should recognize that risk management is a process that begins with a careful risk analysis looking at the types, likelihood, and impact of issues in the design of AVs. Once a risk assessment is complete, they can review the results and analyze changes in design and engineering practices to address these issues, prioritize risks and risk mitigation measures, and implement the prioritized risk mitigation measures [34]. In connection with the risk management process, manufacturers can obtain guidance from a number of standards bearing on risk management and safety:

17 I speak here of product liability litigation, although the risk management techniques here also apply to preventing the need for costly product recalls. 
- ISO 31000 "Risk management - Principles and guidelines" (regarding the risk management process).

- Software development guidelines from the Motor Industry Software Reliability Association.

- IEC 61508 Functional safety of electrical/electronic/programmable electronic safety-related systems (safety standard for electronic systems and software).

- ISO 26262 family of "Functional Safety" standards implementing IEC 61508 for the functional safety of electronic systems and software for autos.

While adherence to the principles of international standards does not guarantee that an AV manufacturer will avoid liability, adherence to standards bolsters the credibility of a manufacturer's risk management program. Moreover, the standards provide a framework by which manufacturers can build a set of controls for their risk management process. Consequently, an AV safety program built on international standards lays the foundation for a later defense of a manufacturer accused of building an unsafe AV.

Fourth, AV manufacturers should obtain insurance coverage to manage product liability risk. A robust insurance program will permit manufacturers to shift the risk of product liability to insurance carriers who will, under issued policies, defend and indemnify manufacturers for settlements and judgments paid to resolve third party claims. Currently, the insurance industry is just beginning to come to grips with the insurance implications of AVs [21]. We can expect to see the insurance industry provide third party coverage to manufacturers for accidents, and probably privacy and information security risks as well. While the industry has no historical data for an actuarial approach to underwriting AV risks, the industry will probably look by analogy to conventional vehicles and mobile devices for loss experiences [6]. AV manufacturers can find carriers willing to write bespoke policies tailormade to their needs. Eventually other carriers will enter the market and offer more standardized polices, thereby reducing premium costs to manufacturers over the long run.

Fifth, manufacturers can work together on industry risk management initiatives, such as:

- Participation in standards efforts to promote safety and security within the industry and among component manufacturers;

- Collaborating with other manufacturers in trade groups and (subject to antitrust concerns) purchasing consortia; with the purchasing power of larger numbers of manufacturers, the industry may have greater leverage with component manufacturers to promote safe design and manufacturing processes; and

- Participation in information sharing groups that can collaborate to develop best practices to improve product safety.

Sixth, manufacturers can manage the risk of huge jury awards by certain pre-litigation strategies. For instance, they may want to engage jury consultants that assist the defense of product liability cases to identify risk factors for the manufacturer and the types of conduct that trigger juror anger. In addition, manufacturers may want to identify and cultivate a 
group of defense experts they can use to educate jurors about various engineering, information technology, and safety considerations. Moreover, counsel for manufacturers may want to join specialty bars for defense counsel for purposes of sharing information, briefs, and other work product.

Finally, manufacturers can maximize their success in future product liability trials by focusing on effective records and information management (RIM). Effective RIM may win cases, while poor RIM may lose cases. Documents and records produced contemporaneously with the management of a safety program can corroborate the testimony of witnesses, provide a historical record documenting a manufacturer's safety efforts, and send the message that the manufacturer cares about safety.

\subsection{Conclusions}

One of the top, if not the top, challenge autonomous vehicle manufacturers face is the risk of product liability suits and recalls in the wake of accidents resulting in deaths and catastrophic injuries. Lawsuits in which manufacturers appear callous, placing profits over safety, face the risk of huge liabilities. Recent reports about "sudden acceleration" in Toyota cars and problems with General Motors' ignition switches show that these companies are paying multiple billions of dollars to resolve legal claims. Plaintiffs have a number of claims they can assert against AV manufacturers, although manufacturers may have defenses as well. Various kinds of defects may crop up with AVs, although problems with software, logic, autonomous behavior, and programmer decisions on AV behavior in crashes are top concerns. Nonetheless, manufacturers can manage product liability risk through careful planning, a strong commitment to safety, an effective risk management process beginning with a thorough risk analysis, adherence to international standards, obtaining robust insurance coverage, collaboration with other manufacturers, pre-litigation legal strategies, and effective records and information management practices. In sum, the threat of crippling product liability litigation in the United States poses a profound concern for manufacturers of autonomous vehicles, but starting proactive engineering design strategies for safety risk management and legal strategies to anticipate future litigation now can place manufacturers in the best position to maximize product safety and minimize product liability in upcoming decades.

\section{References}

1. Alee, John, et al., Product Liability $§ 18.02$ (2014)

2. American Law Institute, Restatement (Second) of Torts $\S 402 A(1)$ (1965)

3. Autonomous Solutions Inc., 5 Key Takeaways from AUVSI's Driverless Car Summit 2012 (Jul. 12, 2012)

4. Barr, Michael, Rule 26(a)(2)(B) Report of Michael Barr April 12, 2013 in Estate of Ida St. John v. Toyota Motor Corporation, et al., 39, 54, 65 (Apr. 12, 2013) 
5. Berenson, Alex, Vioxx Verdict Raises Profile of Texas Lawyer, N.Y. Times, Aug. 22, 2005, available at $\mathrm{http}: / /$ www.nytimes.com/2005/08/22/business/22lawyer.html?pagewanted=all

6. Beyer, David et al., Risk Product Liability Trends, Triggers, and Insurance in Commercial Aerial Robots 20 (Apr. 5, 2014) (describing nascent insurance coverage for drones), available at http:// robots.law.miami.edu/2014/wp-content/uploads/2013/06/Beyer-Dulo-Townsley-and-Wu Unmanned-Systems-Liability-and-Insurance-Trends_WE-ROBOT-2014-Conference.pdf

7. Bookout v. Toyota Motor Corp., No. CJ-2008-7969 (Okl. Dist. Ct. Okl. Cty. dismissed Nov. 20, 2013)

8. Cal. Bus. \& Prof. Code $\S \S 17200$ et seq., 17500 et seq.

9. Cal. Civ. Code $\S 1750$ et seq.

10. CBS News and Associated Press, Toyota "Unintended Acceleration" Has Killed 89, CBS News (May 25, 2010), http://www.cbsnews.com/news/toyota-unintended-acceleration-has-killed-89/

11. Dowle, Mark, Pinto Madness, Mother Jones, Sept. 1977, available at http://www.motherjones. com/print $/ 15406$

12. Fletcher, Michael \& Mufson, Steven, Why did GM take so long to respond to deadly defect? Corporate culture may hold answer, WASH. POST, Mar. 30, 2014, available at http://www. washingtonpost.com/business/economy/why-did-gm-take-...swer/2014/03/30/5c366f6c-b69111e3-b84e-897d3d12b816_story.html

13. Frumer, Louis R., Et AL, Products Liability $§ \S 1.02,2.04,2.05[1], 5.01,8.04$ (2014)

14. Girion, Lisa and Calvo, Dana, Merck Loses Vioxx Case, L.A. Times, Aug. 20, 2005, available at http://articles.latimes.com/2005/aug/20/business/fi-vioxx20

15. Grimshaw v. Ford Motor Co., 119 Cal. App. 3d 757, 771-72, 813, 823-24 (1981)

16. Hendler, John, email to Lori Queen et al. (Sept. 28, 2005, 4:07 pm), http://docs.house.gov/ meetings/IF/IF02/20140618/102345/HHRG-113-IF02-20140618-SD036.pdf

17. Henningsen v. Bloomfield Motors, Inc., 32 N.J. 358, 161 A.2d 69 (1960)

18. Hirsch, Jerry, After losing verdict, Toyota settles in sudden acceleration case, L.A. TIMES, Oct. 25, 2013, available at http://articles.latimes.com/2013/oct/25/autos/la-fi-hy-toyota-settlessudden-acceleration-20131025

19. Isidore, Chris, GM to pay victims at least $\$ 400$ million, CNN MONEY, Jul. 24, 2014, available at http://money.cnn.com/2014/07/24/news/companies/gm-earnings-recall/

20. Krisher, Tom, GM's ignition switch: what went wrong, Columbus Dispatch, Jul. 8, 2014, available at http://www.dispatch.com/content/stories/business/2014/07/08/gms-ignition-switchwhat-went-wrong.html

21. Lloyd's, Autonomous Vehicles Handing Over Control: Opportunities and Risks for Insurance 8 (2014)

22. MacPherson v. Buick Motor Co., 217 N.Y. 382, 111 N.E. 1050 (1916)

23. Merck \& Co., Inc. v. Ernst, 296 S.W.3d 81 (Tex. Ct. App. 2009), cert. denied, 132 S. Ct. 1980 (2012)

24. Minick, Robert D. \& Kagehiro, Dorothy K., Understanding Juror Emotions: Anger Management in the Courtroom, For THE DefEnSE, July 2004, at 2, 3 (emphasis added), available at http://www. krollontrack.com/publications/tg_forthedefense_robertminick-dorothyhagehiro070104.pdf

25. National Highway Traffic Safety Administration, Technical Assessment of Toyota Electronic Throttle Control (ETC) Systems 57-60, 62-64 (Feb. 2011); see NASA Engineering and Safety Center, Technical Support to the National Highway Traffic Safety Administration (NHTSA) on the Reported Toyota Motor Corporation (TMC) Unintended Acceleration Investigation 170-172 (Jan. 18, 2011)

26. Romero, Ric, Sudden Acceleration Issue Spans Beyond Toyota, 6АBC.COM (Jan. 4, 2010), http://6abc.com/archive/7200572/

27. Toyota Motor Corp. Unintended Acceleration Marketing, Sales Practices, and Products Liability Litigation, No. 8:10-ML-2151 JVS (FMO) (C.D. Cal. filed Apr. 12, 2010) (cases consolidated 
by the Judicial Panel on Multidistrict Litigation in the U.S. District Court for the Central District of California)

28. Trop, Jaclyn, Toyota Seeks a Settlement for Sudden Acceleration Cases, N.Y. TimES, Dec. 13, 2013, available at http://www.nytimes.com/2013/12/14/business/toyota-seeks-settlement-forlawsuits.html? r=0

29. Undercoffler, David, Toyota and Justice Department said to reach $\$ 1.2$ billion settlement in criminal case, L.A. TIMES, Mar. 18, 2014, available at http://www.latimes.com/business/autos/ la-fi-hy-autos-toyota-justice-department-settlement-20140318-story.html

30. University of Texas, Autonomous Vehicles in Texas 5 (2014)

31. Vargo, John, Products Liability Practice Guide $\S \S 6.02[1], 6.02[4], 6.03[1], 6.04$ (2014)

32. Winterbottom v. Wright, 152 Eng. Rep. 402 (1842)

33. Worstall, Tim, When Should Your Driverless Car From Google Be Allowed To Kill You?, ForBES, available at $\mathrm{http}: / / \mathrm{www}$. forbes.com/sites/timworstall/2014/06/18/when-should-your-driverlesscar-from-google-be-allowed-to-kill-you (Jun. 18, 2014)

34. Wu, Stephen, Risk Management in Commercializing Robots 6-8 (Apr. 3, 2013), available at http://conferences.law.stanford.edu/werobot/wp-content/uploads/sites/29/2013/04/RiskManagement-in-Commercializing-Robotics.pdf

35. Yoshida, Junko, Toyota Case: Single Bit Flip That Killed, EE TIMEs, Oct. 25, 2013 